\title{
Optimizing The Role of Zakat and Wakaf in Promoting National Economic Growth: Analytic Network Process (ANP) Method Approach
}

\author{
Robithoh Alam Islamy ${ }^{1}$, Mulawarman Hannase ${ }^{2}$ \\ ${ }^{1}$ Universitas Indonesia \\ ${ }^{2}$ Universitas Indonesia \\ email: r_alamislamy@yahoo.com,mhannase@yahoo.com
}

\begin{abstract}
This study aims to determine the criteria and aspects of optimizing the role of zakat and infaq. This research's further objective is to build a model that can be used to determine criteria and priority aspects to become input for related parties to improve the role of zakat and waqf. This study combines descriptive qualitative and quantitative research using the Analytic Network Process (ANP) method. In building models and calculations, experts are involved in producing results following conditions in the field. This study indicates that zakat and waqf have played a role in encouraging national economic growth. Aspects that become alternatives in optimization are aspects of policy/legality/institutional, technical aspects of operations/databases, human resources/management aspects, aspects of auditing/control, socialization/community literacy, and cooperation aspects. The criteria used in selecting alternatives are effective criteria (collection and distribution) and efficient criteria (cheap, fast, and applicable). The ANP model connects alternatives and criteria and calculates that the order of priority from the highest to the lowest is 1. Policy, Legality, and Institutions (47.28\%); 2. Human Resources/Management Aspects (13.94\%), 3. Socialization Aspects (12.66\%); 4. Cooperation Aspects (12.54\%); 5. Operational/Database Technical Aspects (8.27\%) and; 6. Audit/Control Aspects (5.29\%).
\end{abstract}

Keywords: Zakat, Waqf, Economic Growth, Analytic Network Process/ANP. 


\section{INTRODUCTION}

The welfare of people in Indonesia shows that the government considers government's economic growth more than economic welfare. Indonesia's Gini ratio is still high, at 38.1\% (DEKS Bank Indonesia-P3EI-FE UII, 2016). The figure exceeds the GINI ratio of OIC member countries, which has a value of $21 \%$. The GINI ratio, which has a value above the average of OIC countries, indicates that Indonesia's income equality is still below that of the country.

The high Gini ratio can have unintended social, societal effects such as high crime and violence at all levels of society. Such conditions will certainly be contrary to the expected goal of achieving economic welfare so that economic equality is an essential concern for the government. Economic growth occurs in line with all community members' overall economic improvement (DEKS Bank Indonesia-DES-FEB Unair, 2016).

Achievement of economic growth that is evenly distributed throughout the community can be achieved with zakat provision. The vital role of zakat for economic growth in Indonesia can be measured by involving zakat in measurement indicators. One way to assess the influence of zakat is to do correlation analysis. The results of the correlation analysis can show a link between economic growth and zakat. This will be a strong handle to involve zakat throughout economic activities to achieve continuous economic development (DEKS Bank Indonesia-P3EI-FE UII, 2016).

Islam has a focus on equitable distribution. The source of crisis or inequality is the uneven distribution of income that causes the condition of resource inequality (economy) (Center for Islamic Economic Assessment and Development (P3EI) UII Yogyakarta, 2014). With the equitable distribution of both property and services, a fair economic distribution mechanism will be created in the community. It is expected that inequality, poverty, and unemployment can be minimized.

The application of various property provisions in Islam, such as zakat, infaq, sadaqah, and waqf, functions in the community as a counterweight to economic growth (Bank Indonesia, 2017). This 
function is carried out so that the improvement of existing property in the community is not limited to the welfare of individuals but also provides benefits to the community as a whole to achieve mutual welfare through the step of spending some of the wealth (QS Al Hadid: 7; QS An-Nuur: 33; QS Al Baqarah: 267-268). Applying the basic principles expressed in Islam will make the individual's property better to improve society's economic level. This condition certainly supports the UN target in fulfilling the Sustainable Development Goals (SDGs), aiming to maintain the balance and continuity of holistic community life in the world.

The primacy of basic principles in Islam, especially zakat, has not been felt to the maximum in Indonesian society because of the not optimal zakat management. The cause of this minimum achievement is the zakat collecting institutions' condition, which is also caused by a lack of public knowledge about zakat implementation. People today still have the belief that zakat is sourced in traditional forms with certain conditions clearly stated in the Qur'an and hadith (Hafidhuddin, 2002; Majid and Muhammad, 2003). Moreover, Huda and others (2018) stated that the provision of zakat must be stated in the rules and strict implementation of the government so that every Muslim in a country carries out the provision of zakat from excess property that has reached nishab. The strict rules and implementation are expected to ensure significant zakat receipts to be used as a device that helps maintain a country's economic stability.

Efforts to develop Islamic Social Finance (ISF) aimed at the realization of a prosperous society stated the importance of optimization of ISF (DEKS Bank Indonesia, 2017) one of which is zakat and waqf with the consideration that:

1. Sharia's economic and financial development is essential to support the nation's resilience and welfare.

2. Islamic Social Finance (ISF) has excellent potential to be one of the solutions.

3. ISF optimization efforts are essential, including increased accountability in governance: ZCP and WCP, development of various ziswaf management optimization models, and 
integration of sharia commercial and social finance to expand inclusiveness.

In connection with the exposure related to the above, efforts are needed to optimize the role of zakat and waqf in encouraging national economic growth through improvement in all lines, ranging from policy aspects/legality/institutional, operational, technical aspects/databases, aspects of HUMAN RESOURCES/ management, aspects of audit/control, aspects of socialization/ public literacy, and aspects of Cooperation.

This research is needed to know how to optimize zakat and waqf's role in Indonesia by knowing the most priority alternatives using ANP. The primary purpose of the research is then detailed into several objectives. The first objective is to know the role of zakat and waqf in encouraging national economic growth. The purpose of the research is also intended to determine the aspects and criteria in the management of zakat and waqf. The next objective is to build an ANP model for optimizing the role of zakat and waqf and then, based on the model. An ANP calculation carries out the process to determine aspects and priority criteria for zakat and waqf.

\section{LITERATURE REVIEW Zakat and Waqf Studies}

The meaning of Zakat from Ashshidieqy and Shiddieqy (1999) is according to the language has the meaning of the nama' (fertility), taharah (chastity), barakah (blessing). According to Hafidhuddin (1998), another meaning of zakat is zaka, which means 'holy,' 'good,' 'blessing,' 'growing,' and 'developing' (Mu'jam Wasith, I:398). Zakat also means tazkiyah, tathier (purifying). Allah is All-Knowing, All-All-Important.

The definition of zakat is also expressed by today's writers such as Ali (1988), An-Nabhani, (1996), and Nasution and others (2010). Ali (1988) stated that zakat is an obligation on the property stipulated in every eligible Muslim. The property is then given to certain people on the condition that nishab, haul, and level. An- 
Nabhani (1996) stated that zakat is worship in Islam in the form of delivering the property of a Muslim whose wealth (outside of debt and needs) meets a mishap. Nasution and others (2010) state that zakat is an obligation to spend a portion of the income/ property of a person who has fulfilled Islamic sharia requirements to be given to social elements that have been stipulated in Islamic sharia.

While waqf is in a language derived from the Arabic word waqafa, which means to stop, dwell (Ali, 1988) According to Khosyi'ah (2010), the synonym of the word waqf is habs, which means to hold. If the two things are combined, then Ibn Mandzur (1954: 276) mentions al-hubus wa wuqifa (detained and being waqf) (DEKS Bank Indonesia-DES-FEB Unair, 2016). Something that is withheld or stopped in the waqf sense is property. The purpose of the cessation or detention of the property is to benefit the individual and the community.

The Law on Waqf in Indonesia is contained in Law No. 41 of 2004, which seeks to summarize the four great scholars' definition. Based on the Law, waqf is declared as an action carried out by wakif based on the law and carried out by setting aside the assets owned to become assets used for the public or religious interests whose utilization period is whether at the agreed time interval or forever (Law No. 41 of 2004). Various definitions of waqf that have been described above both that have been given by the scholars of 4 sects and in Law No. 41 of 2004 as a whole is a form of utilization of property of a Muslim for the public interest that is justified in Islamic law both within a certain period and for good.

Research on the impact of zakat on taxes was conducted by Djatmiko (2019). The study results showed that the zakat scenario as income tax deduction has a more significant impact on the economy than if zakat is used to deduce taxable income. The impact of zakat on economic growth is also researched by Setiadi (2019). The study results stated that both zakat funds and other social funds such as infaq and alms impact economic growth. 
Comprehensive research conducted on the problem of Zakat in Indonesia and sought solutions using the Analytic Hierarchy Process approach. The research suggested that zakat collection is still low caused by 3 (three) aspects: regulatory aspects, aspects of zakat management organization, and community aspects.

In the regulatory aspect, the implementation of zakat law has not been implemented into a mandatory system in the state's financial governance. Making the level of awareness and compliance of the community mandatory zakat is still lacking. In the Zakat Management Organization (OPZ) aspect, problems arise related to human resources managers/amil LAZ. Another thing that becomes a deficiency in this aspect of OPZ is the low synergy between stakeholders zakat both from LAZ institutions, mustahik, muzakki, and other related parties. The main problem in this aspect of society is the poor understanding of zakat and fikih zakat in the community, especially in people who have the potential as muzakki and distribution of zakat not through institutions directly to ashnaf.

Further research on low zakat collection in Indonesia was conducted by Ascarya and Yumanita (2018). There are 3 (three) main aspects that become problems in collecting zakat, namely internal, external, and system problems.

The difference between previous research and research today is expanding the scope of management problems that previously only included zakat. This study also includes waqf.

\section{Analytical Network Process (ANP)}

Analytical Network Process (ANP) is a qualitative method that can help search for factors that affect a system. The central concept in ANP is the comparison of pairs between factors/criteria or alternatives. The scale used in the comparison can be seen in Table 1. The pairing comparison can then be used in calculating the most priority criteria and alternatives in the role optimization model of zakat and waqf by using ANP (Ascarya, 2005). 
Table 1. Comparison of Verbal Scale and NUMERICAL Scale of ANP

\begin{tabular}{|c|c|}
\hline Verbal Scale & $\begin{array}{c}\text { Numerical } \\
\text { Scale }\end{array}$ \\
\hline It is a lot more of an influence & 9 \\
\hline & 8 \\
\hline Much greater influence & 7 \\
\hline & 6 \\
\hline Greater influence & 5 \\
\hline & 4 \\
\hline A little more influence & 3 \\
\hline & 2 \\
\hline Just as much influence & 1 \\
\hline
\end{tabular}

Source: (Ascarya, 2005)

The solution step using ANP is taken from the basic principles of ANP, namely:

1. Decomposition Step

Decomposition is done by examining the problem and then simplifying the problem to be described with an ANP model consisting of clusters, sub-clusters, or if necessary, using sub-clusters. In addition to the restructuring of elements, it also assessed the relationship between elements and clusters.

2. Valuation step of Comparative judgments

The next comparison assessment is carried out using the pairwise comparison of all combinations of elements in the cluster and cluster comparison based on decomposition in the next step.

3. Step hierarchical composition or synthesis of priorities.

The last step of the ANP is the formation of synthesis based on values and models that have been formed in the previous step. The synthetic result is an element of the priority value.

\section{METHODS}

The method used in this research is a qualitative and quantitative descriptive method using Analytic Network Process (ANP) approach in finding the solution. Research using this 
method requires data in primary data obtained from interviews (in-depth interviews) with experts, practitioners, and regulators. Experts involved are experts who master the problems discussed, namely the optimization of zakat and waqf. After discussing the model at the first meeting, the questionnaire was conducted at the second meeting. The interview results and the filling of the questionnaire were then entered into an ANP application with the respondent's assessment variables on the problem that became the research object on a numerical scale.

This research used the ANP method described in several stages of research (see Figure 1). The following are five stages of research that need to be done:

1. The first stage, researchers collect data through literature studies, then group the aspects to be optimized, solutions/ programs, and strategies/policies in depth.

2. The second phase, researchers compiled an ANP construction model of this study, which included problems, criteria, and strategies, and compiled a pair comparison questionnaire.

3. In the third phase, researchers surveyed respondents involving regulators, academics/experts, and practitioners to fill out questionnaires and provide ratings and scales of 1-9 to each element. Before filling out the questionnaire, experts were asked to review the questionnaire to equalize understanding and make the questionnaire more structured. After the questionnaire was deemed appropriate, the expert filled out the questionnaire. Then the researchers did data validation and consistency tests.

4. Phase four, researchers process and analyze data. Furthermore, the results of the study can be analyzed and validated.

5. Phase five, researchers interpret the results of existing data analysis to draw conclusions and provide recommendations to the relevant parties. 
Journal of Islamic Economic Laws-January, Vol. 4, No. 1, 2021

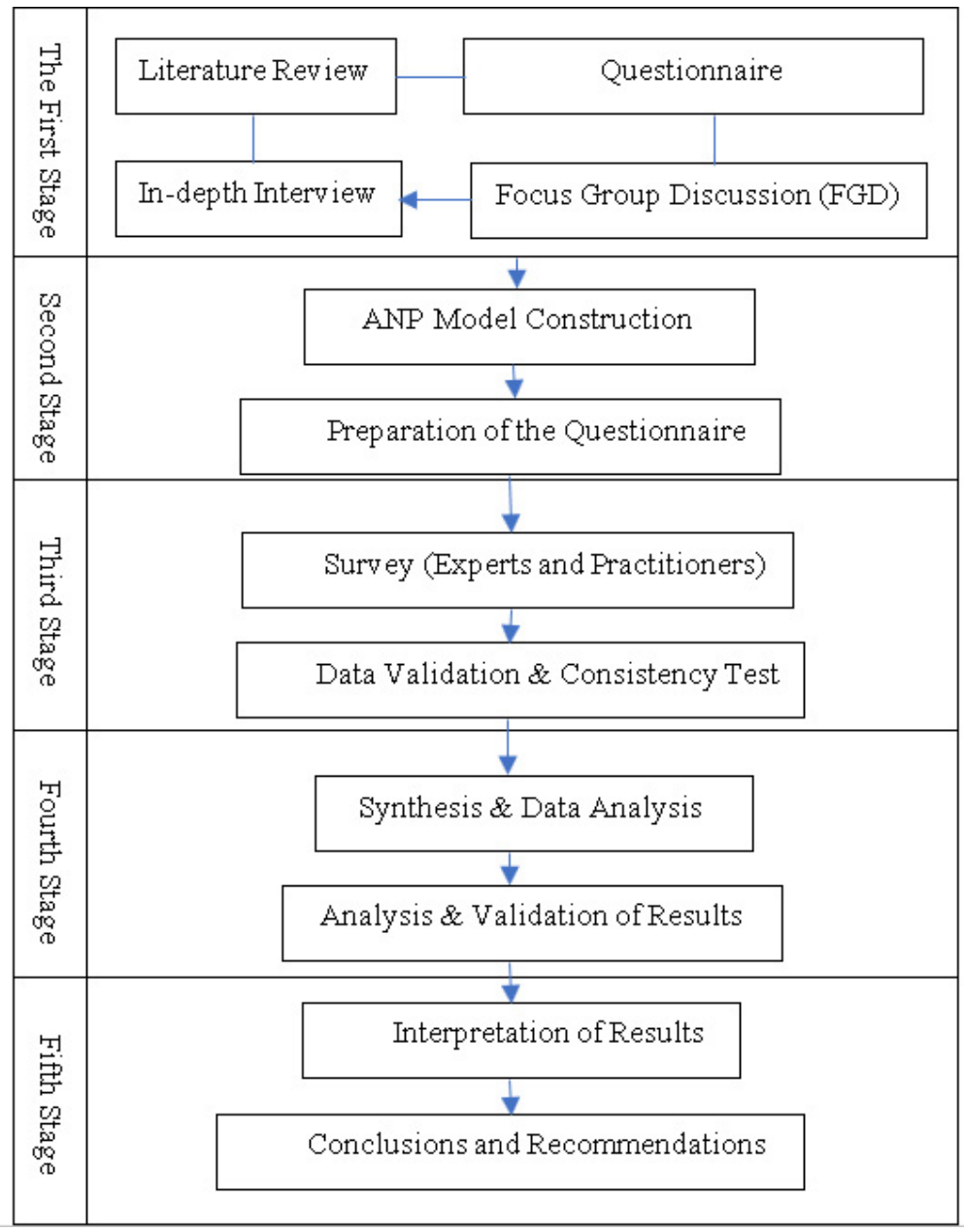

Figure 1. Research Stages Scheme Diagram

\section{RESULTS AND DISCUSSION}

Based on research on literature, it is known that things area improvement of aspects of optimization of zakat and waqf management as in Figure 2. Based on research, then built an ANP model.

The ANP Model optimization role of Zakat and Waqf was developed by determining the alternatives and criteria used in the model. In this model, alternatives are obtained from studies that produce optimization aspects in Figure 2. Sufficient criteria and efficiency are formulated from the study on the size of 
optimization on zakat and waqf. Effective and efficient criteria are then re-defined into sub-criteria detailing the size used. The alternatives and criteria obtained are then built into an ANP model that has been validated by experts, namely in Figure 3 .

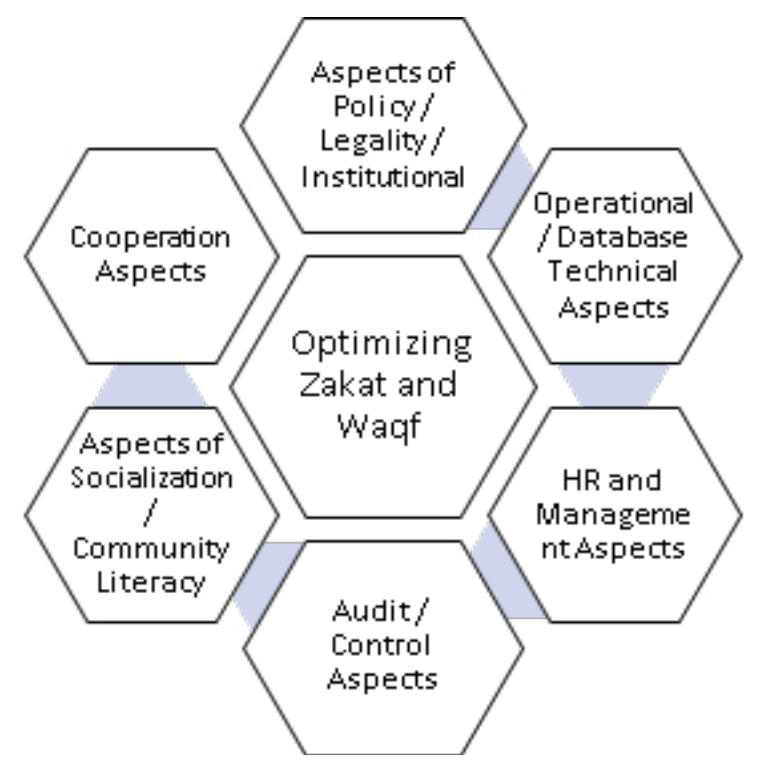

Figure 2. Aspects of Zakat and Waqf Optimization

\section{Questionnaire Result Data}

Questionnaires were developed to build an ANP model of zakat, and Waqf Optimization aims to get a pairwise comparison between clusters, alternative clusters, and criteria clusters. The questionnaire is then given to experts to fill in the comparison value between nodes/clusters. 




Figure 3. ANP Model Optimizes the Role of Zakat and Waqf

Reference experts in filling out comparison values in questionnaires using values in Table 1. The results of the questionnaire by pakar can be seen in Table 2 .

Table 2. Paired Comparison Questionnaire Results

\begin{tabular}{|c|c|c|c|c|}
\hline No & Cluster/Node & $\begin{array}{c}\text { Comparative } \\
\text { Analysis } \\
\end{array}$ & Score & Cluster /Node \\
\hline 1. & Effective & $\begin{array}{l}\text { has bigger } \\
\text { effect than }\end{array}$ & 5 & Efficient \\
\hline \multirow[t]{6}{*}{2.} & \multicolumn{4}{|c|}{ Comparison of Alternatives to Sub Criteria 'Fast' } \\
\hline & $\begin{array}{l}\text { Policy/Legality/ } \\
\text { Institutional }\end{array}$ & $\begin{array}{l}\text { has much } \\
\text { bigger effect } \\
\text { than }\end{array}$ & 7 & $\begin{array}{l}\text { Technical } \\
\text { Operations/ } \\
\text { Database }\end{array}$ \\
\hline & $\begin{array}{l}\text { Policy/Legality/ } \\
\text { Institutional }\end{array}$ & $\begin{array}{l}\text { has bigger } \\
\text { effect than }\end{array}$ & 5 & $\begin{array}{l}\text { Human Resources/ } \\
\text { Management }\end{array}$ \\
\hline & $\begin{array}{l}\text { Policy/Legality/ } \\
\text { Institutional }\end{array}$ & $\begin{array}{l}\text { has bigger } \\
\text { effect than }\end{array}$ & 5 & Auditing/Control \\
\hline & $\begin{array}{l}\text { Policy/Legality/ } \\
\text { Institutional }\end{array}$ & $\begin{array}{l}\text { has bigger } \\
\text { effect than }\end{array}$ & 5 & $\begin{array}{l}\text { Socialization/ } \\
\text { Community } \\
\text { Literacy }\end{array}$ \\
\hline & $\begin{array}{l}\text { Policy/Legality/ } \\
\text { Institutional }\end{array}$ & $\begin{array}{l}\text { has bigger } \\
\text { effect than }\end{array}$ & 5 & Cooperation \\
\hline
\end{tabular}




\begin{tabular}{|c|c|c|c|c|}
\hline No & Cluster/Node & $\begin{array}{c}\text { Comparative } \\
\text { Analysis } \\
\end{array}$ & Score & Cluster /Node \\
\hline & $\begin{array}{l}\text { Technical } \\
\text { Operations/ } \\
\text { Database }\end{array}$ & $\begin{array}{l}\text { has slightly } \\
\text { smaller effect } \\
\text { than }\end{array}$ & 4 & $\begin{array}{l}\text { Human Resources/ } \\
\text { Management }\end{array}$ \\
\hline & $\begin{array}{l}\text { Technical } \\
\text { Operations/ } \\
\text { Database }\end{array}$ & $\begin{array}{l}\text { has slightly } \\
\text { smaller effect } \\
\text { than }\end{array}$ & 4 & Auditing/Control \\
\hline
\end{tabular}

\section{Data Processing}

The value obtained from the questionnaire is inputted and processed in the Super Decisions application. The expected output of such processing is:

1. Available comparisons between alternatives with between criteria.

2. Available alternatives are best following the criteria set out to optimize the role of Zakat and Waqf.

Details of an ANP processing using Super Decisions applications are grouped for each cluster. One example of processing in the comparison between criteria clusters is described with paired comparisons between Effective Criteria and Efficient Criteria.

In comparison between effective and efficient clusters evaluated based on alternative clusters, sufficient criteria are more important than efficient criteria (see Figure 4). The results obtained in the comparison resulted in an incontinence value of 0.000 , which means that the resulting pairing comparison matrices are consistent.

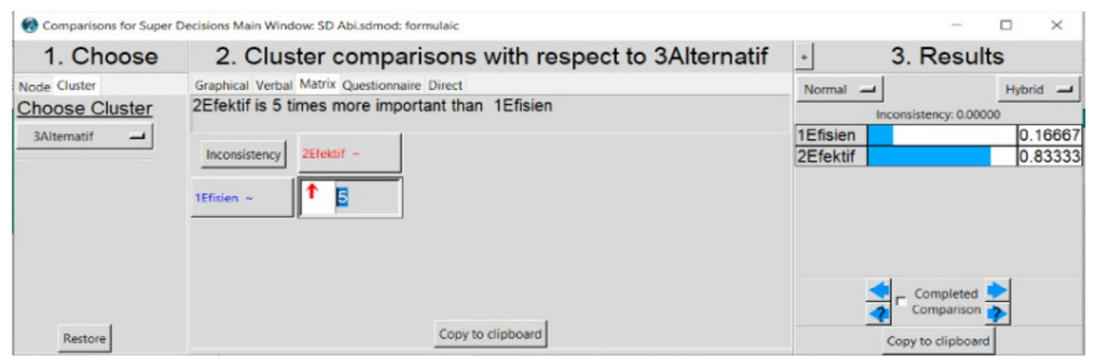

Figure 4. Comparison Results of Effective Criteria with Efficient Criteria 
Examples of pairing comparisons between sub-criteria and alternate clusters are exemplified in the pairing comparison between Fast-Efficient and Alternative Sub-Criteria. Comparing fast sub-criteria inefficient clusters and all nodes on alternate criteria can be seen in the comparison matrix in Figure 5 .

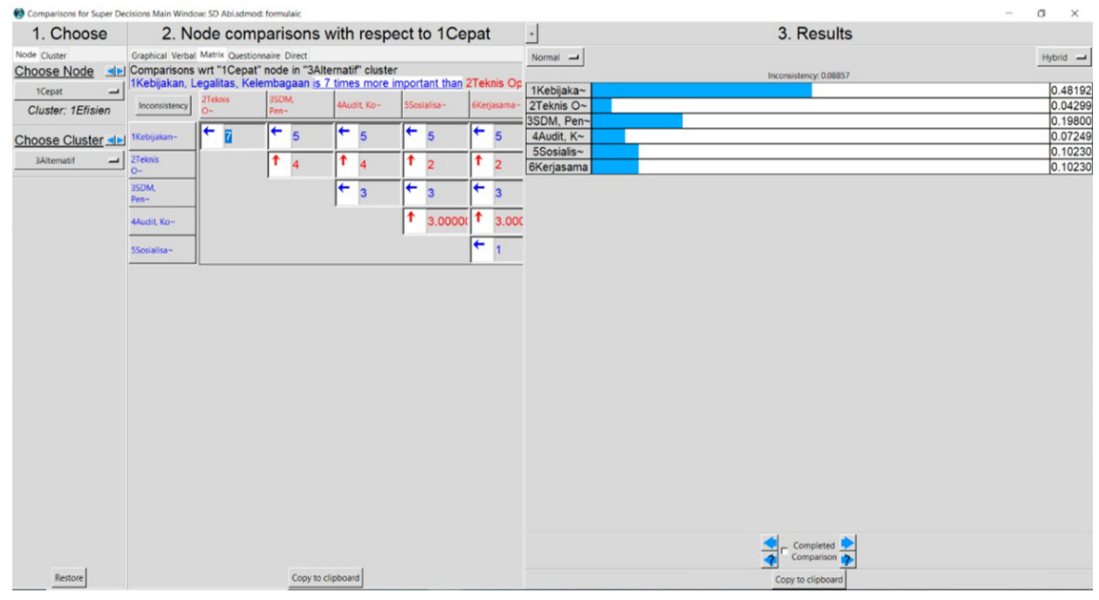

Figure 5. Paired Comparison Results of Fast-Efficiency Sub Criteria with Alternative Criteria

Calculation of inconsistencies in the matrix can also be seen in Figure 5. The result is 0.08857 . This indicates that the table is consistent. Each aspect's weight value calculated to the fast subcriteria can be seen as the order of interest in all aspects. Based on the calculation results obtained, the order of interest from the most important to the least important are as follows: Policy, Legality and Institutional (0.48192), Human Resources and Management (0.19800), Socialization and Cooperation (0.10230), Audit and Control (0.07249), and lastly operational technical aspects (0.04299).

Reporting Research Results

The inserted ANP inputs then generates a priority matrix containing the normalized weights of all the alternatives and criteria used on the model. The results of the data processing can be seen in Figure 6 . 
The data processing results in Figure 6 are known as alternative priorities and criteria resulting from an ANP calculation. Based on calculations, priority criteria are divided into 2 clusters, namely Effective clusters and Efficient clusters. The cluster results are compelling, the collection sub-criteria weights 0.53166 , and the distribution sub-criteria has a value of 0.46834 . This indicates that the collection sub-criteria has a higher weight than the distribution sub-criteria.

In efficient clusters, it was obtained that fast sub-criteria weighted 0.33934 , the cheap sub-criteria weighted 0.27287 , and the applicable sub-criteria weighted 0.38779 . This indicates that the sub-criteria with the highest priority is applicable, followed by fast sub-criteria and cheap sub-criteria.

Alternative clusters result in aspect weight values to be optimized listed in Table 3. The table shows that alternative aspects of policy, legality, and institutional have the highest priority value to be implemented. The next aspect is Human Resources and Management, followed by aspects of Socialization and Community Literacy, aspects of Cooperation, Aspects of Operational Technical/Database, and aspects with the least priority aspect of Audit/Control.

\begin{tabular}{|c|c|c|c|}
\hline \multicolumn{4}{|c|}{ Here are the priorities. } \\
\hline Icon & Name & Normalized by Cluster & tlimiting \\
\hline No icon & $\begin{array}{l}\text { 1Kebijakan, Legalitas, } \\
\text { Kelembagaan }\end{array}$ & 0.47287 & 0.236437 \\
\hline No icon & $\begin{array}{l}\text { 2Teknis Operasional, } \\
\text { Database }\end{array}$ & 0.08267 & 0.041336 \\
\hline No icon: & 3SDM, Pengelolaan & 0.13943 & 0.069715 \\
\hline No icon & 4Audit, Kontrol & 0.05298 & 0.026492 \\
\hline No icon & 5Sosialisasi & 0.12665 & 0.063324 \\
\hline No icon & 6Kerjasama & 0.12539 & 0.062696 \\
\hline No icon & 1Cepat & 0.33934 & 0.028278 \\
\hline No Icon & 2Murah & 0.27287 & 0.022739 \\
\hline No icon & 3Aplikatif & 0.38779 & 0.032316 \\
\hline No icon & 1Penghimpunan & 0.53166 & 0.221526 \\
\hline No icon & 2 Penyaluran & 0.46834 & 0.195141 \\
\hline
\end{tabular}

Figure 6. Final Results of ANP Calculation 
Table 3. Alternative Priority Value based on ANP Calculation

\begin{tabular}{clc}
\hline Priority & \multicolumn{1}{c}{ Aspects } & Value \\
\hline 1 & Policy, Legality, and Institutional & 0,47287 \\
2 & Human Resources and Management & 0,13943 \\
3 & Socialization and Community Literacy & 0,12665 \\
4 & Cooperation & 0,12539 \\
5 & Operational Technical and Database & 0,08267 \\
6 & Audit and Control & 0,05298 \\
\hline \multicolumn{2}{c}{ Total } \\
\hline
\end{tabular}

\section{CONCLUSION}

Zakat and waqf have played a role in boosting national economic growth, namely by increasing national income, playing a role in boosting economic performance, maintaining economic activity. This role is positively correlated in suppressing social and political turmoil, increasing total investment in the economy, which is then used to finance social activities.

Aspects in the management of zakat and waqf are policy aspects, legality, institutional, Operational Technical aspects/ Database, aspects of Human Resources/Management, aspects of Audit/Control, aspects of Socialization, and aspects of Cooperation. Criteria in the management of zakat and waqf are Effective and Efficient. Effective Criteria has a sub-criteria for collection and distribution. Efficient Criteria has a sub-criterion Fast, Cheap, and Applicable.

Model Analytic Network Process (ANP) in optimizing zakat and waqf's role has 3 clusters: 1: alternative clusters containing six alternative aspects; 2 : effective criteria cluster containing two sub-criteria; 3: an efficient criteria cluster containing three subcriteria. The three clusters are connected. Both criteria clusters are connected in two directions with alternate clusters. There is no relationship between the two criteria clusters in this model, which means that the model still assumes no connectedness (influence) between the two clusters.

The resulting priority aspects are Priority 1: Policy, Legality, and Institutional Aspects (47.28\%); 2. Human Resources/ Management Aspects (13.94\%), 3. Socialization Aspects 
(12.66\%); 4. Aspects of Cooperation (12.54\%); 5. Operational Technical Aspects/Database (8.27\%) and Audit/Control Aspects $(5.29 \%)$. The priority sub-criteria in the Effective Criteria is Collection. The priority sub-criteria in Efficient Criteria is Applicable.

This research recommends that the government establish policies, legalities, and institutions related to the management of zakat and waqf, among others, by revising the law to strengthen advice for regulators to carry out the functions of regulation, supervision, guidance, and the imposition of sanctions more effectively. Advice for the operator is to run the management professionally in line with ZCP and WCP. For the community, to carry out the obligations of zakat and waqf recommendations with full obedience based on worship to Allah SWT. For academics, in order to deepen research and research related to efforts to optimize zakat and waqf. Advice for government, regulators, scholars, and community leaders try to improve understanding, knowledge, and public awareness (education and literacy) related to zakat and waqf.

\section{REFERENCES}

Ali, M. D. (1988). Sistem ekonomi Islam: Zakat dan wakaf. Penerbit Universitas Indonesia.

An-Nabhani, T. (1996). Membangun sistem ekonomi Alternatif;Perspektif Islam. Risalah Gusti.

Ascarya. (2005). Analytic Network Process (ANP): Pendekatan baru studi kualitatif. Pusat Pendidikan dan Studi Kebanksentralan, Bank Indonesia.

Ascarya, \& Yumanita, D. (2018). Analisis rendahnya pengumpulan zakat di Indonesia dan alternatif solusinya.

Ashshidieqy, M. H., \& Shiddieqy, F. H. A. (1999). Pedoman zakat. Pustaka Rizki Putra.

Bank Indonesia. (2017). Cetak biru pengembangan ekonomi dan keuangan syariah.

DEKS Bank Indonesia-DES-FEB UNAIR. (2016). Wakaf: Pengaturan dan tat kelola yang efektif. Seri ekonomi dan 
keuangan syariah. Departemen Ekonomi dan Keuangan Syariah-Bank Indonesia.

DEKS Bank Indonesia-P3EI-FE UII. (2016). Pengelolaan Zakat yang efektif: Konsep dan praktik di beberapa negara. seri ekonomi dan keuangan syariah. Departemen Ekonomi dan Keuangan Syariah-Bank Indonesia.

DEKS Bank Indonesia. (2017). Mendorong pengembangan islamic social finance dalam rangka mewujudkan masyarakat sejahtera.

Djatmiko, H. (2019). Re-formulation zakat system as tax reduction in Indonesia. Indonesian Journal of Islam and Muslim Societies, 9(1), 135-162.

Hafidhuddin, D. (1998). Panduan praktis tentang zakat infak sedekah. Gema Insani.

Hafidhuddin, D. (2002). Zakat dalam perekonomian modern. Gema Insani.

Huda, N., \& And Others. (2018). Ekonomi Makro Islam: Pendekatan Teoritis. Prenada Media.

Huda, N., Anggraini, D., Ali, K. M., Rini, N., \& Mardoni, Y. (2014). Solutions to Indonesian zakah problems analytic hierarchy process approach. Journal of Islamic Economics, Banking, and Finance, 113(3279), 1-17.

Khosyi'ah, S. (2010). Wakaf \& Hibah (perspektif ulama fiqh dan perkembangannya di Indonesia) (Vol. 1, Issue 1). CV. Pustaka Setia.

Majid, M. N., \& Muhammad. (2003). Pemikiran ekonomi Islam Abu Yusuf: relevansinya dengan ekonomi kekinian. Pusat Studi Ekonomi Islam (PSEI), Sekolah Tinggi Ilmu Syari’ah (STIS).

Nasution, M. E., \& others. (2010). Pengenalan eksklusif ekonomi Islam, cet. 3. Jakarta: Prenada Media Group.

Pusat Pengkajian dan Pengembangan Ekonomi Islam (P3EI) UII Yogyakarta. (2014). Ekonomi Islam. PT Grafindo Persada. 
Setiadi, A. (2019). Pengaruh instrumen dana sosial keislaman terhadap pertumbuhan ekonomi (studi pada lima provinsi di Indonesia). Universitas Brawijaya. 